US/USSR AGREEMENT ON SCIENCE AND TECHNOLOGY

CONF-7909152--1

PROCEEDINGS OF THE FIFTH JOINT US/USSR

CONFERENCE OF THE MICROBIAL ENZYME REACTIONS

PROJECT OF THE US/USSR JOINT WORKING GROUP

ON THE PRODUCTION OF SUBSTANCES BY MICRO-

BIOLOGICAL MEANS,

Jurmala (Riga) Latvia, USSR

September 30 - October 5, 1979

Edited by,

H. H. Weetall, Conference Chairman Corning Glass Works

Corning, New York 14830

H. R. Bungay, Co-coordinator Project IV Rensselaer Polytechnic Institute

Troy, New York 12181

Sponsored by the US/USSR Joint Working Group on the Production of Substances by Microbiological Means and supported by the American Society for Microbiology through a contract with the National Science Foundation 


\section{DISCLAIMER}

This report was prepared as an account of work sponsored by an agency of the United States Government. Neither the United States Government nor any agency Thereof, nor any of their employees, makes any warranty, express or implied, or assumes any legal liability or responsibility for the accuracy, completeness, or usefulness of any information, apparatus, product, or process disclosed, or represents that its use would not infringe privately owned rights. Reference herein to any specific commercial product, process, or service by trade name, trademark, manufacturer, or otherwise does not necessarily constitute or imply its endorsement, recommendation, or favoring by the United States Government or any agency thereof. The views and opinions of authors expressed herein do not necessarily state or reflect those of the United States Government or any agency thereof. 


\section{DISCLAIMER}

Portions of this document may be illegible in electronic image products. Images are produced from the best available original document. 


\section{PAGES 1 to 479 WERE INTENTIONALLY LEFT BLANK}




\title{
PHOTOBIOLOGICAL HYDROGEN PRODUCTION
}

\author{
M. Seibert, S. Lien, and P. F. Weaver \\ Solar Energy Research Institute* \\ Golden, Colorado 80401 USA
}

Hydrogen production by phototrophic organisms, which has been known since the 1930 's, occurs at the expense of light energy and electron-dunaling substrates. Three classes of organisms, namcly, photosynthetic bacteria, cyanobacteria, and algae carry out this function. The primary hydrogen-producing enzyme systems, hydrogenase and nitrogenase, wi.17 be discussed along with the manner in which they couple to light-driven electron transport. In addition, the feasibility of using in vivo and in vitro photobiological hydrogen producing. systems in future solar energy conversion applications will be examined.

*A division of the Midwest Research Institute. This work was sponsored by the U.S. Department of Energy under Contract EG-77-C-01-4042. 


\section{INTRODUCTION}

Although the ability to take up or evolve molecular $\mathrm{H}_{2}$ is not a common phenomenon in the biosphere, it is prevalent among photosynthetic microorganisms. Photosynthetic bacteria, cyanobacteria (formerly known as blue-green algae), and eucaryotic algae carry out both functions. However, the emphasis of this overview will be on the latter. Before discussing the current status of photobiological $\mathrm{H}_{2}$ production, it is first necessary to examine the enzymes that catalyze $\mathrm{H}_{2}$ metabolism and the manner in which the photosynthetic apparatus is coupled to them in a functional system.

Two general classes of enzymes, hydrogenase and nitrogenase, are closely associated with the final $\mathrm{H}_{2}$-evolving act in photosynthetic microorganisms. However, the primary functions of the enzymes are. quite distinct. Nitrogenase is normally operative in biological nitrogen fixation whereas hydrogenase normally catalyzes hydrogen uptake or consuming reactions. Nevertheless, under certain conditions both can catalyze a different reaction, the photoproduction of $\mathrm{H}_{2}$

\section{ENZYMES}

\section{Hydrogenases}

Hydrogenases are iron-sulfur proteins which generally contain four moles (or multiples thereof) of both iron and inorganic sulfide per mole of enzyme. Purified hydrogenases have a molecular weight of 
about 50,000 to 200,000 daltons. Chromatium vinosum, Thiocapsa roseopersicina, and Rhodospirillum rubrum hydrogenases are relativeliy heat stable. The first two are also among the most stable hydrogenases in air. T. Horio (personal communication) has recently crystallized the third.

A large number of organisms have been assayed for hydrogenase activity. Representative examples are given in Table 1. Nearly all photosynthetic bacteria contain hydrogenase as do about $50 \%$ of the algal strains tested (2). Nonphotosynthetic organisms are included in the table since their hydrogenases may prove useful for in vitro photoconversion systems discussed later. Reports of hydrogenase activity in higher plants and animals may be due to associations with contaminating microorganisms.

\section{Nitrogenases}

Nitrogenase, which has been characterized in nonphotosynthetic organisms, is an enzyme complex consisting of two proteins, one containing iron (the Fe protein) and the other containing both molybdenum and iron (the MoFe protein). Both are necessary for nitrogenase activity.

The MoFe proteins from all sources are $\mathrm{O}_{2}$-labile, have molecular weights of approximately 220,000 daltons, and have one or two types of subunits. Approximately two moles of molybdenum and $24-32$ moles of iron and sulfide are found per mole of protein. 
The $\mathrm{Fe}$ proteins are also $\mathrm{O}_{2}$-labile. Molecular weights average about 60,000 daltons, and the protein consists of two subunits of equal weight. The presence of four irons and four sulfides per. protein molecule and a $\underline{g}=1.94$ EPR signal suggest that the active site may be similar to that of bacterial ferredoxins; that is, of the $\mathrm{Fe}_{4} \mathrm{~S}_{4}$ configuration.

The Fe protein is reduced by dithionite and is also the site of Mg-ATP binding. The Mg-ATP-Fe protein complex has a redox midpoint potential below $-400 \mathrm{mV}$ which is sufficient to reduce the MoFe protein. Rivera-Ortiz and Burris (3) have suggested that all of the substrates for nitrogenase, including $\mathrm{N}_{2}$ and $\mathrm{H}^{+}$, bind to the MoFe protein (though at different sites) where they compete for the MgATP-reduced Fe protein complex.

Table 2 lists a number of representative organisms which exhibit nitrogenase activity. Nitrogenase is an extremely common, if not universal, enzyme in photosynthetic bacteria. However, it is difficult to ascertain its ubiquity in cyanobacteria since oxygenic photosynthesis in these microbes is inherently incompatible with the nitrogenase protein. Of 122 strains of nonheterocystous cyanobacteria tested, Stanier and Cohen-Bazire (4) found 43 which synthesized nitrogenase. No example of nitrogen fixation in a eucaryote has been confirmed as yet. 


\section{IN VIVO COUPLING TO PHOTOSYNTHETIC ELECTRON TRANSPORT}

\section{Photosynthetic Bacteria}

$\mathrm{H}_{2}$ photoproduction in photosynthetic bacteria is mainly associated with nitrogenase rather than hydrogenase activity and is coupled to reduced ferredoxin or flavodoxin in those cases delineated. It requires ATP and is inhibited by $\mathrm{N}_{2}$ or $\mathrm{NH}_{4}^{+}$.

How do photosynthetic bacteria generate strong reductants at the level of ferredoxin to carry out nitrogenase-coupled $\mathrm{H}_{2}$ evolution? The possibilities are threefold. Ferredoxin is reduced 1) directly by a light-driven reaction; 2) indirectly by ATP-driven reversed electron transport or; 3) by dehydrogenation or oxidative decarboxylation reactions of intermediary metabolism not involving electron transport chains. Fig. 1 illustrates the three possibilities. The main evidence for the first coupling mechanism is found in Chlorobium, a green sulfur bacterium. This organism has a primary acceptor ( $X^{\prime}$ in the figure) with a redox midpoint potential lower than $-450 \mathrm{mV}$ (5) which is sufficiently negative to reduce ferredoxin and hence nitrogenase. In most other photosynthetic bacteria, the primary acceptor is $U Q \cdot F e\left(E_{m, 7} \simeq-180 \mathrm{mV}\right)$ which can not reduce ferredoxin directly, and $X^{\prime}$ has not been demonstrated. Rather, ferredoxin reduction may occur by an ATP-driven reversal of electron flow from substrate-reduced cytochromes (6). There is evidence for reversed electron flow from succinate to $\mathrm{NAD}^{+}$, but it occurs only at low 
rates, and the reduction of ferredoxin has not been demonstrated. In the third coupling mechanism the function of light is relegated to that of providing optimal levels of ATP through cyclic phosphorylation. In this model reductant generation may be accomplished through the phosphoroclastic cleavage of pyruvate (7).

\section{Algae}

The photosynthetic apparatus of eucaryotic algae contain two photosystems as illustrated in Fig. 2. The primary photochemical reactions of photosystem II (PSII) produces a strong oxidant which splits water in a multiphoton reaction in addition to a weak reductant which donates electrons to photosystem I (PSI) through a series of redox carriers. The light reaction of PSI uses that electron to produce a strong reductant which is more negative than the hydrogen electrode. $\mathrm{H}_{2}$ production is coupled to photosynthesis through ferredoxin and is catalyzed by an anaerobically adaptable hydrogenase which is able to store two electrons and combine them with two protons. There has been some controversy about the source of reducing equivalents (water or organic substrates), but this point will be addressed in our second paper.

\section{Cyanobacteria}

Cyanobacteria are photosynthetic procaryotes situated between photosynthetic bacteria and green algae, on the evolutionary scale. They derive electrons for $\mathrm{CO}_{2}$ reduction from water (and thus evolve 
$\mathrm{O}_{2}$ ) as do green algae, but some also fix $\mathrm{N}_{2}$ as do photosynthetic bacteria.

Photosynthetic electron transport in cyanobacteria is quite similar to that in algae and higher plants. Both PSII and PSI operate in series and cover redox potential ranges similar to those of algae. Most of the electron transport redox carriers are similar or identical to those in eurcaryotic photosynthetic organisms.

The limited information available on $\mathrm{H}_{2}$ photoproduction in cyanobacteria is restricted to the $\mathrm{N}_{2}$-fixing species, which contain both nitrogenase and hydrogenase. Nitrogenase is the active enzyme in this case, and due to its oxygen-sensitivity somc filamentous organisms (including Anabaena) differentiate heterocysts to protect the enzyme. Heterocysts maintain an anaerobic environment for nitrogenase and do not evolve $0_{2}$. They receive reducing equivalents from vegetative cells (via normal oxygenic photosynthesis) and produce low potential reductants and ATP in reactions associated with PSI (Fig. 3).

\section{IN VIVO HYDROGEN-GENERATING SYSTEMS}

The current energy crisis has prompted renewed interest in microbial photosynthetic $\mathrm{H}_{2}$ evolution because of its potential for use in applied solar energy conversion systems.

Intact photosynthetic bacteria cultures offer the most immediate potential. The technology is probably available now, and functioning 
systems could be built if suitable low-cost metabolizable substrates were available. We and $\mathrm{Dr}$. Weetal will discuss these possibilities in other papers at this workshop, but laboratory evolution rates of between 0.6 and $176 \mathrm{ml} \mathrm{H}_{2} \cdot \mathrm{mg}^{\mathrm{dry}} \mathrm{wt}^{-1} \cdot \mathrm{hr}^{-1}$ have been obtained depending upon the organism and the condition (1).

$\mathrm{H}_{2}$ production by green algae remains a highly transitory event, lasting from a few minutes to several hours. Up until now, the maximum transient rates reported range from 48 to $70 \mu$ moles $\mathrm{H}_{2} \cdot \mathrm{mg} \mathrm{Chl}^{-1} \cdot \mathrm{hr}^{-1}$ (8). This is far below the average rate of steady state photosynthesis which is equivalent to 200-300 $\mu$ moles $\mathrm{H}_{2} \cdot \mathrm{mg} \mathrm{Chl}^{-1} \cdot \mathrm{hr}^{-1}$. Longer term $\mathrm{H}_{2}$ production rates are much lower than the transient rates. The low rates are due primarily to the sensitivity of hydrogenase to photosynthetically generated $0_{2}$, but competitive processes including photosynthetic $\mathrm{CO}_{2}$ fixation, photoreduction, auto-oxidation reactions, and the oxy-hydrogen reaction are also evident. The development of an efficient algal $\mathrm{H}_{2}$ evolution system will require a clear understanding of the basic biochemical events involved in each of these in vivo metabolic processes as well as elucidation of the detailed mechanisms controlling electron flow from the reducing side of PSI to the various low potential redox reactions within the cell.

$\mathrm{H}_{2}$ photoproduction by cyanobacteria can occur in the presence of atmospheric $\mathrm{O}_{2}$, and recently, Benemann has done much to improve the rates: By manipulating the amount of $\mathrm{N}_{2}$ and $\mathrm{CO}_{2}$ in Ar sparging gas and using $\mathrm{N}$-starved cultures, he has obtained laboratory con- 
version efficiencies of $1.7 \%$ and solar conversion efficiencies of $0.2 \%$ (9). However, energy costs due to circulation of the sparging gas makes the system impractical as yet.

Several two-stage systems which separate $\mathrm{H}_{2}$ and $\mathrm{O}_{2}$ evolution either temporally or spatially have been suggested. Benemann has proposed the former (Fig. 4A), and Weetall and Krampitz have demonstrated the latter (Fig. 4B). So far the rates obtained have been low $(2.5$ $\mu$ moles $\cdot \mathrm{ml}^{-1} \cdot \mathrm{hr}^{-1}$, ref. 10$)$, but the concept is quite intriguing. IN VITRO $\mathrm{H}_{2}$-GENERATING SYSTEMS

Cell-free $\mathrm{H}_{2}$ generation employing isolated spinach chloroplasts, ferredoxin, Chromatium hydrogenase, and cysteine was first demonstrated twenty years ago(11). Recent improvements have used water as a substrate, increased average $\mathrm{H}_{2}$ evolution rates by a factor of 6 , and lengthened the operating duration from less than fifteen minutes to between two and six hours (Table 3). Unfortunately, these improvements represent only a modest step toward the development of an efficient, practical cell-free system because they were obtained only when $\mathrm{O}_{2}$ - and $\mathrm{H}_{2} \mathrm{O}_{2}$ - scavengers were included in the reaction mixture. Economically the use of scavengers is not practical; however, the real significance of these experiments lies in the fact that they demonstrate the technical feasibility of in vitro coupling of the water-splitting reaction of photosynthesis to hydrogenase. 
Finally, 01son (12) has suggested a specific geometry which could eliminate the $\mathrm{O}_{2}$ problem. In Fig. 5 he proposes to separate the $\mathrm{O}_{2}$ and $\mathrm{H}_{2}$ evolution function by an artificial membrane (not as yet available) which is impermeable to both gases but which allows for the transfer of a redox carrier. The chamber on the right is composed of PSII-containing vesicles which split water. That on the left contains vesicles incorporating Chlorobium reaction centers which theoretically can reduce ferredoxin and hydrogenase. A mobile electron-proton carrier (C) shuttles reductant to the left where $\mathrm{H}_{2}$ is produced in the light. The system has the advantage of using different parts of the solar spectrum to drive each of two light reactions.

\section{CONCLUSION}

Although the future potential for photobiological $\mathrm{H}_{2}$ production systems is encouraging, it is clear that additional basic information about $\mathrm{H}_{2}$ metabolism in microorganisms must be obtained. Of all the schemes outlined above, that utilizing photosynthetic bacteria shows the most promise for nearer term applications. 


\section{REFERENCES}

1. Weaver, P., S: Lien, and M. Seibert. 1979. Photobiological Production of Hydrogen-A Solar Energy Conversion Option. SERI TR33-122.

2. Kessler, E. 1974. In Algal Physiology and Biochemistry (W.D.P. Stewart, ed.). Blackwe17, Oxford. pp. 454.

3. Rivera-Ortez, J. M., and R. H. Burris. 1975. J. Bacteriol. 123: 537.

4. Stanier, R. Y., and G. Cohen-Bazire. 1977. Ann. Rev. Microbiol. 31:225.

5. Prince, R. C., and J. M. 01 son. 1976. Biochem. Biophys. Acta. 423:357.

6. Gest, H. 1966. Nature. 209:879.

7. Bennett, R., N. Rigopoulos, and R. C. Fuller. 1964. Proc. Nat'l Acad. Sci. U.S.A. 52:762.

8. McBride, A. C., S. Lien, R. K. Togosaki, and A. San Pietro. 1977. In Biological Solar Energy. Conversion (A. Mitsui et al., eds). Academic Press, N.Y. pp. 77.

9. Benemann, J. R., and P. S. Hallenbeck. 1978. In Hydrogenases: Their catalytic Activity, Structure, and Function. (H. G. Schlegel and K. Schneider, eds.). Erick Goltze K. G., Gottingen. Pp. 395.

10. Krampitz, L. 0. 1977. In Clean Fuels from Biomass and Waste (W. W. Watermann, ed.). Institute of Gas Technology.

11. Arnon, D. I., A. Matsui, and A. Paneque. 1961. Science. 134:1425.

12. 01son, J. M. 1979. Abstracts, The Electrochemical Society Spring Meetings. pp. 711. 
Table 1. REPRESENTATIVE ORGANISMS EXHIBITING HYDROGENASE ACTIVITY

ORGANISM

REFERENCE (see ref. l)

Photosynthetic Bacteria

Rhodospirillum rubrum

Rhodopseudomonas capsulata

Rhodomicrobium vannielii

Chromatium vinosum

Thiocapsa roseopersicina

Chlorobium thiosulfatophilum

Cyanobacteria

Anabaena cylindrica

Synechococcus elongatus

Synechocystis sp.

Nostoc muscorum

Euglenoid

Euglena gracilis

Omerod and Gest, 1962

Klemme, 1968

Hoare and Hoare, 1969

Roel ofsen, 1934

Gogotov et al. , 1976

Pfennig and Trliper, 1974

Hattori, 1963

Frenkel et al., 1950

Frenkel et al. 1950

Ward, 1970

Hartman and Krasna, 1963

Green Algae

Chlamydomonas reinhardti i

Chlorella fusca

Scenedesmus obTiquus

UTva lactuca

Hartman and Krasna, 1963

Kessler, 1974

Gaffron and Rubin, 1942

Frenkel and Rieger, 1951

Red Aigae

Porphyra umbilical is

Porphyriduim cruentum

Frenkel and Rieger, 1951

Frenkel and Rieger, 1951

Brown Algae

Ascophyllum nodosum

Frenkel and Rieger, 1951

Nonphotosynthetic Bacteria

Escherichia coli

Klebsiella pneumoniae

Alcaligines eutrophus

Desulfovibrio vulgaris

Clostridium pasteurianum

Methanobacterium sp.

Rhizobium leguminosarum

Azotobacter vinelandii.

Stephenson and Stickland, 1931

Ordal and Halvorson, 1939

Repaske, 1962

Yagi et al., 1968

Peck and Gest, 1954

Bryant et al., 1967

Dixon, 1967

Hyndman et al., 1953 
Table 2. REPRESENTATIVE ORGANISMS EXHIBITING NITROGENASE ACTIVITY

$$
\text { ORGANISM }
$$

$$
\text { REFERENCE (see ref.1) }
$$

Photosynthetic Bacteria

Rhodospirillum rubrum

Rhodopseudomonas capsulata

Rhodomicrobium vannielii

Chromatium sp.

Thiocapsa roseopersicina

Chlorobium sp.

Kamen and Gest, 1949

Lindstrom et al., 1951

Lindstrom et a $\frac{\text { a }}{\text {. , } 1951}$

Lindstrom et al., 1950

Gogotov, $1 \overline{978}$

Lindstrom et a]., 1950

Cyanobacteria

Anabaena cylindrica

Nostoc muscorum

Gleothece sp.

Plectonema boryanum

Fogg, 1942

Wilitiams and Burris, 1952

Rippka et al., 1971

Stewart and Lex, 1970

Nonphotosynthetic Bacteria

Klebsiella pneumoniae

Clostridium pasteurianum

Rhizobium japonicum

Penga and Wilson, 1958

Azotobacter vinelandi i

Desulfovibrio sp.

Rosenblum and Wilson, 1949

Hoch et a . , 1960

Burris et ai., 1943

Sisler and ZoBell, 1951 
Table 3. LIGrt-INDUCED He Production IN CBLL-FRRa COUPLBD STSTEMS

\begin{tabular}{|c|c|c|c|c|c|c|c|}
\hline \multicolumn{2}{|c|}{ References (see ref. 1) } & \multirow{2}{*}{$\begin{array}{l}\text { Ma jor Components } \\
\mathrm{Cp}+\mathrm{Fd}+\mathrm{H}_{2} \text { ase }(\underline{\mathrm{C}} \cdot \underline{\text { kluyveri })}\end{array}$} & \multirow{2}{*}{$\begin{array}{l}\text { Electron } \\
\text { Sources } \\
\mathrm{H}_{2} \mathrm{O} \\
\mathrm{U}_{2}^{0} \\
\text { ASC + OPIP }\end{array}$} & \multirow{2}{*}{$\frac{\begin{array}{c}\text { Onygen } \\
\text { Irapa }\end{array}}{+}$} & \multirow{2}{*}{ 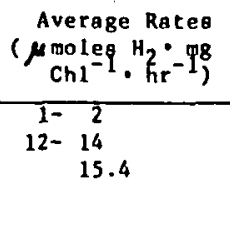 } & \multirow{2}{*}{$\begin{array}{l}\begin{array}{c}\text { Operating } \\
\text { Duratiom } \\
\text { (hr) }\end{array} \\
0.25 \\
?\end{array}$} & \multirow{2}{*}{$\begin{array}{l}\text { Comments } \\
\text { Rate Falls off to } 25 t \text { after } 15 \\
\text { min. Stability of the syatem not } \\
\text { inveat } 1 \text { gated with } 0_{2} \text { trap or donor } \\
\text { gystea. }\end{array}$} \\
\hline & $\begin{array}{l}\text { Benemann et al } \\
(1973)\end{array}$ & & & & & & \\
\hline 2. & $\begin{array}{l}\text { Ben-Amotz and Gibbs } \\
(1975)\end{array}$ & 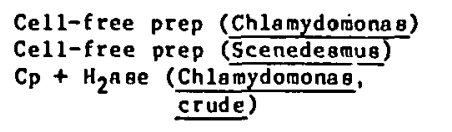 & $\begin{array}{l}\text { DTT or NADH } \\
\text { DTT } \\
\text { DTT }\end{array}$ & $\overline{-}$ & $\begin{array}{l}2 \\
3.6 \\
4.3\end{array}$ & $\begin{array}{l}1-1.5 \\
1 \\
1\end{array}$ & Rate falle off after 60 to $90 \mathrm{mLn}$. \\
\hline 3. & $\begin{array}{l}\text { Krasnovsk11 et } \text { ell.. } \\
(1975)\end{array}$ & 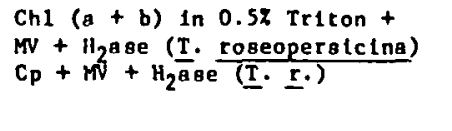 & $\begin{array}{l}\text { NADH } \\
\text { NADH }\end{array}$ & - & $\begin{array}{r}11.5 \\
8.2\end{array}$ & $?$ & $\begin{array}{l}\text { The rate value of } 11.5 \text { was eat1- } \\
\text { aated fron the absorbance reading } \\
\text { of Chl }(a+b) \text { given by the } \\
\text { authors. }\end{array}$ \\
\hline 4. & $\begin{array}{l}\text { Roo et } \\
(1976)\end{array}$ & 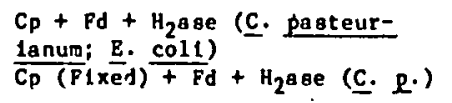 & $\begin{array}{l}\mathrm{H}_{2} \mathrm{O} \\
\mathrm{H}_{2} \mathrm{O} \\
\mathrm{H}_{2} \mathrm{O}\end{array}$ & 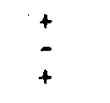 & $\begin{array}{r}9-15.5 \\
2.8 \\
11.5\end{array}$ & $\begin{array}{r}3-6 \\
3 \\
3\end{array}$ & $\begin{array}{l}\text { Cp (Fixed) repreaents chloroplast } \\
\text { fixed in } 0.052 \text { glutaraldehyde. }\end{array}$ \\
\hline s. & $\begin{array}{l}\text { Reeves et al.., } \\
(1976)\end{array}$ & $C_{p}+\mathrm{Pd}+\mathrm{H}_{2} \mathrm{age}$ & $\mathrm{H}_{2} \mathrm{O}$ & + & $20-(40)$ & 3 & $\begin{array}{l}\text { The rate value of } 40 \text { is the maximum } \\
\text { value given by authors. No primary } \\
\text { data was presented. }\end{array}$ \\
\hline 6. & $\underset{(1977)}{\operatorname{Fry}}$ et & $\begin{array}{l}\mathrm{Cp}+\mathrm{Pd}+\mathrm{H}_{2} \mathrm{ase} \text { (C. pasteur- } \\
\text { lanum) }\end{array}$ & $\mathrm{H}_{2} \mathrm{O}$ & + & $7-13$ & 2-6 & \\
\hline & $\begin{array}{l}\text { Hof fmann et } \text { al.. } \\
(1977)\end{array}$ & $\begin{array}{l}C_{p}+H V \text { or Fd or Triquat }+ \\
H_{2} \text { ase (c. pasteurlanum) }\end{array}$ & DAD or TMPD & - & $50-125$ & 0.17 & $\begin{array}{l}\text { Stabllity of the gystem was not } \\
\text { inveatigated. }\end{array}$ \\
\hline 8. & $\begin{array}{l}\text { Rao et } \text { a1.. } \\
(1978)\end{array}$ & 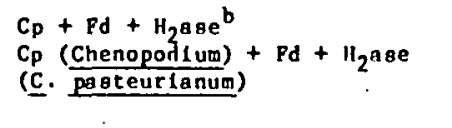 & $\begin{array}{l}\mathrm{H}_{2} \mathrm{O} \\
\mathrm{H}_{2} \mathrm{O}\end{array}$ & + & $\begin{array}{r}30-(50) \\
(94)\end{array}$ & 2 & $\begin{array}{l}\text { The rate values } 50 \text { and } 94 \text { were } \\
\text { maximum values ment } 1 \text { oned by } \\
\text { authora. No primary data was } \\
\text { presented. }\end{array}$ \\
\hline
\end{tabular}

Rey for Abbrevlationg: ASC, ascorbate; Chl, chlorophy1l; $C_{P}$, chloroplagts (when not opectfled, vere frow optnach or pea); DAD, diaminodurene; oPtP, dichlorophenol Indophenol: DTT, dithlothreltol; Fd, ferredoxin; Hase, hydrogennse; MV, methyl vlologen; NADH, reduced form of nlcotinamide adenine

Af nucleotide; MPD, N-tetramethyl-p-phenylenedlamine. glucose-glucose oxidase system was further converted by ethanol-catalase to the acetalaldehyde and $\mathrm{H}_{2} \mathrm{O}$ whict are less reactive. Original references

b) Hydrogenages frow various source were uged giving the different rates of hydrogen production. 


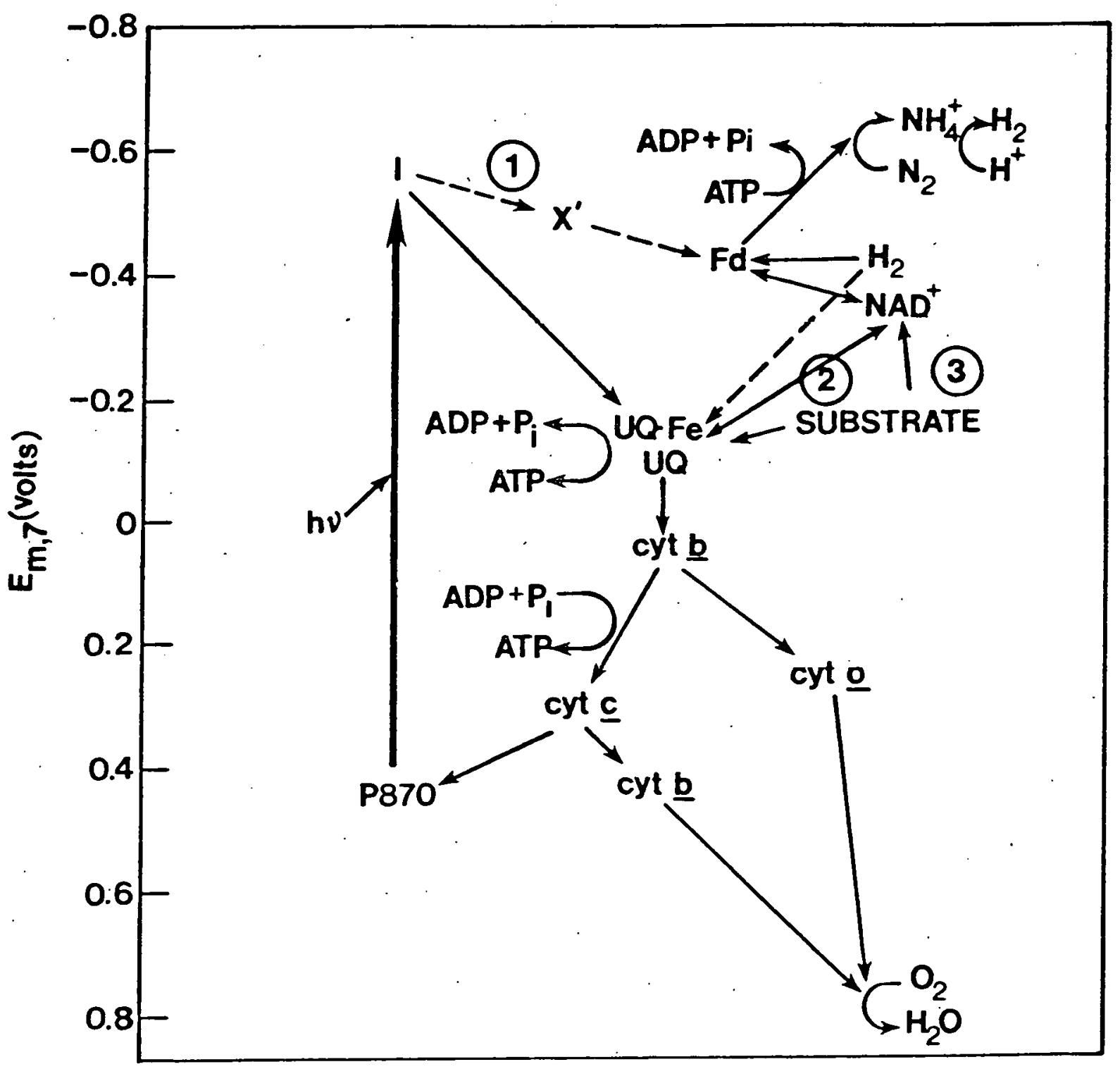

FIGURE 1. ELECTRON TRANSPORT IN PHOTOSYNTHETIC BACTERIA AND ITS RELATIONSHIP TO $\mathrm{N}_{2}$ FIXATION AND $\mathrm{H}_{2}$ METABOLISM.

Three possible pathways by which photosynthetic bacteria might generate strong reductants at the level of ferredoxin (Fd) to carry out nitrogenase coupled $\mathrm{H}_{2}$ evolution. UQ. $\mathrm{Fe}$ is the classical "primary" acceptor, a ubiquinone/iron complex. See the text for an explanation of $X^{\prime}$. 


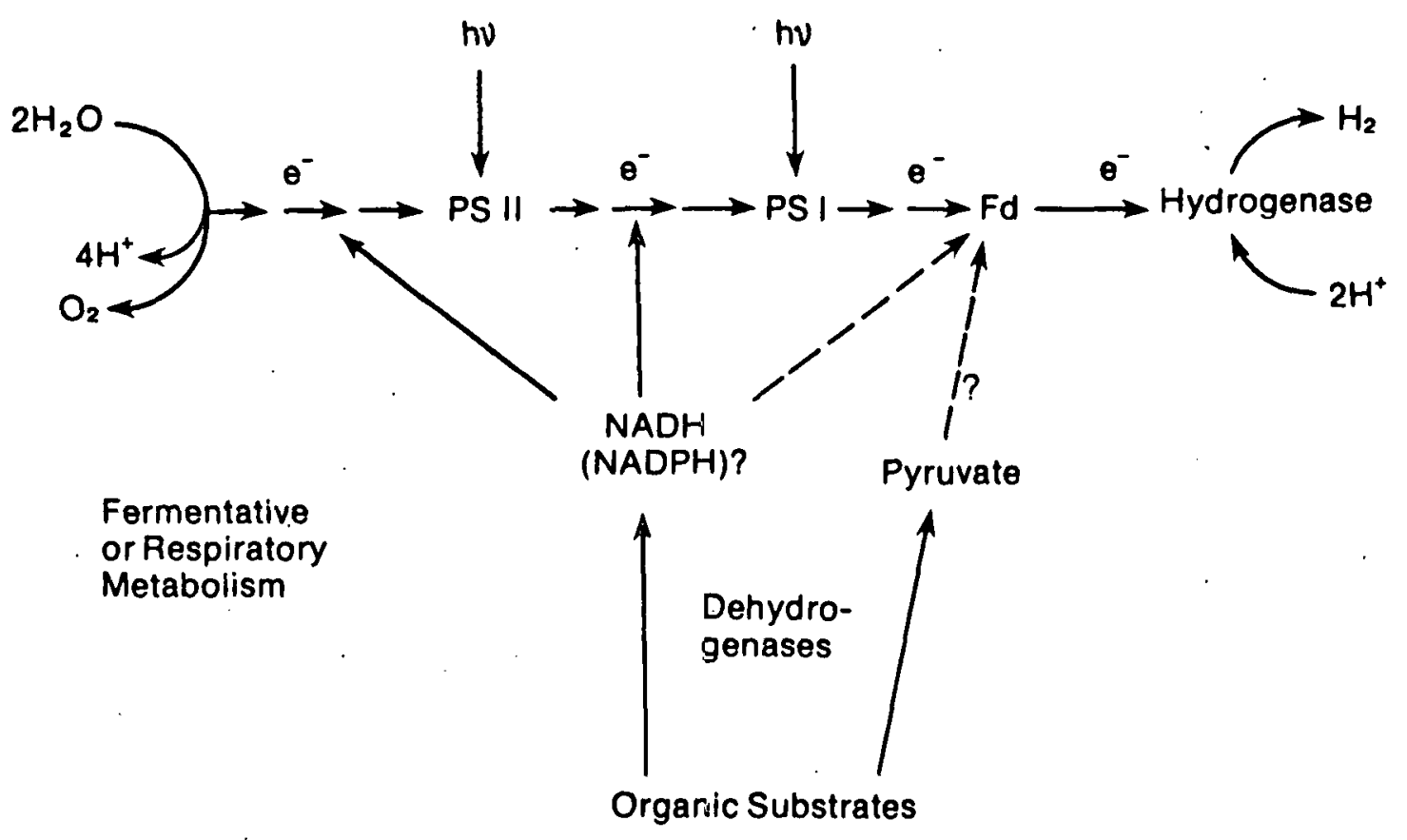

FIGURE 2. IN VIVO HYDROGEN PRODUCTION IN ALGAE Hydrogen evolution is mediated by hydrogenase, which is directly coupled to ferredoxin (Fd). Reduced ferredoxin can be supplied by direct light-driven reactions or by dark metabolic reactions. 


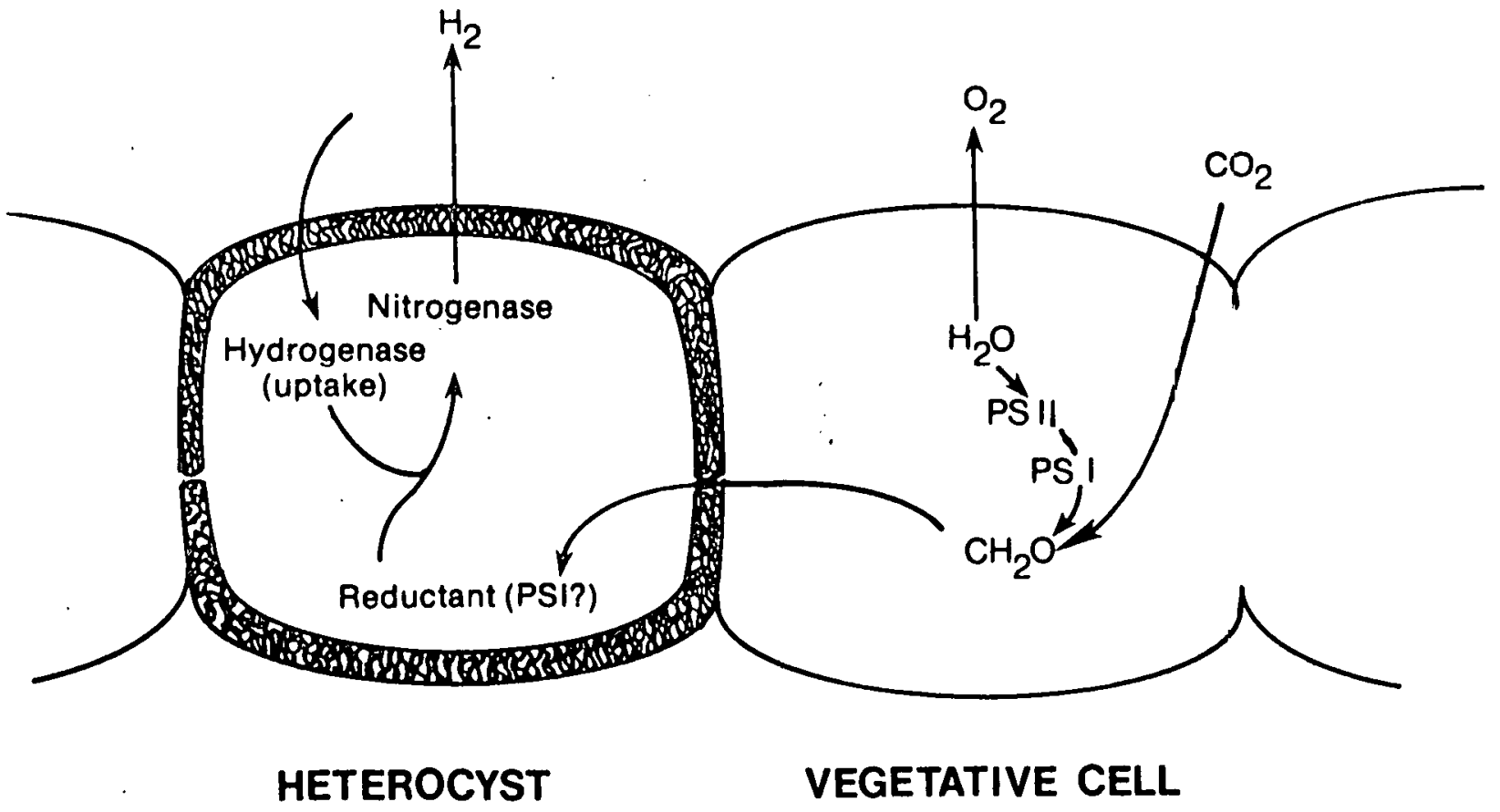

FIGURE 3. HYDROGEN METABOLISM IN CYANOBACTERIA 
A. Temporal
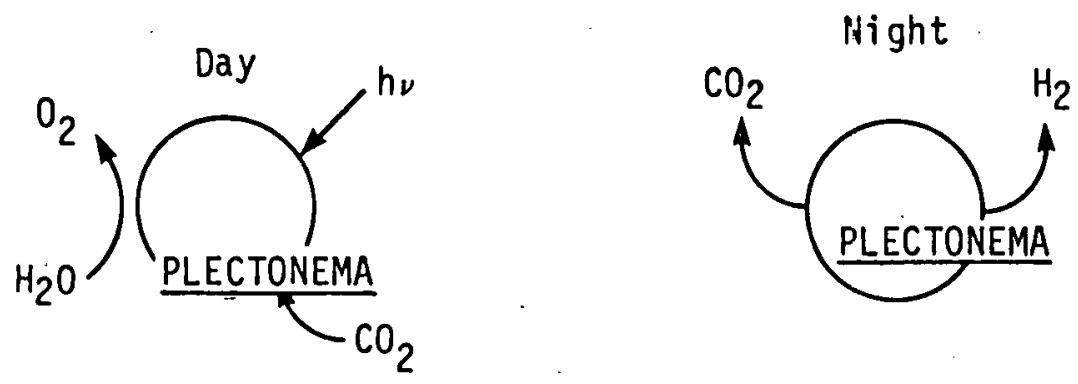

B. Multiorganism

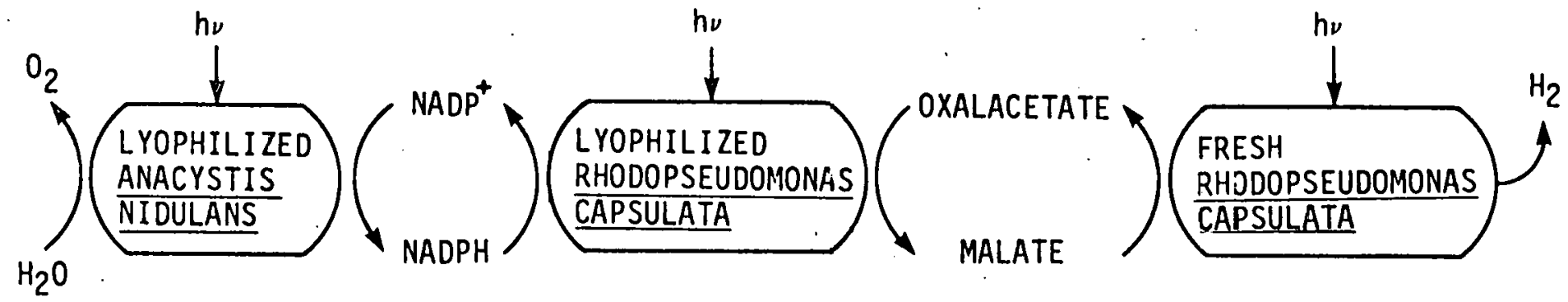

FIGURE 4. TWO-STAGE BIOLOGICAL $\mathrm{H}_{2}$ PRODUCTION SYSTEMS USING WHOLE CELLS.

A. Temporal system in which $\mathrm{O}_{2}$ and $\mathrm{H}_{2}$ evolution occur at different times.

B. Multiorganism system in which $\mathrm{O}_{2}$ and $\mathrm{H}_{2}$ evolution are separated in space. 


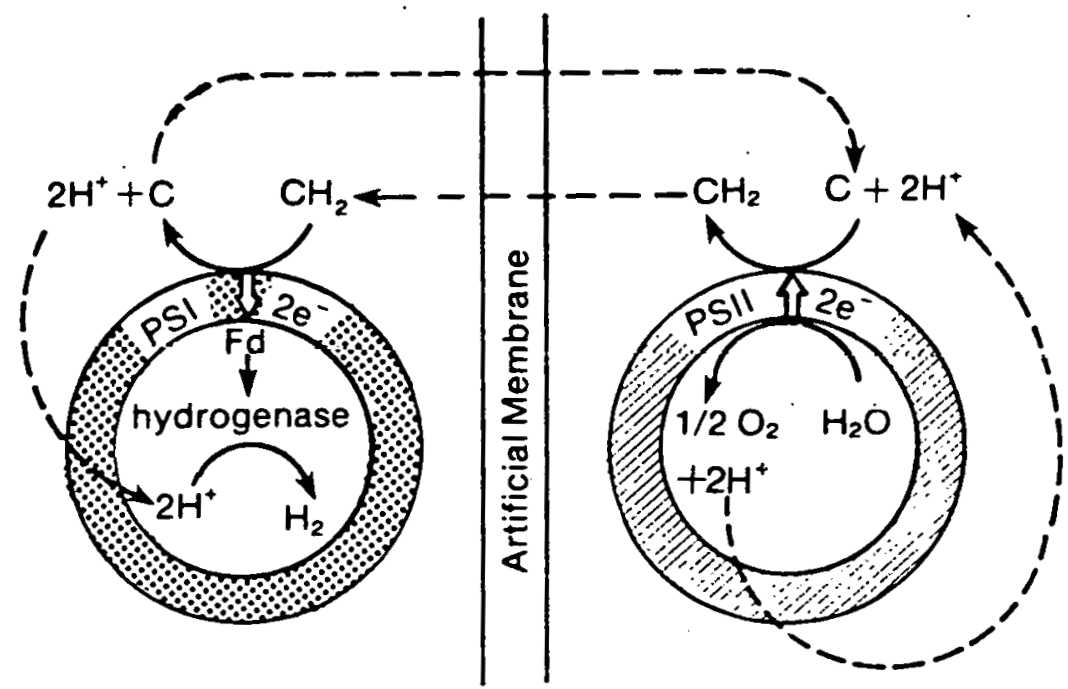

FIGURE 5. AN IN VITRO HYDROGEN PRODUCTION SYSTEM PSI- and PSII-containing vessicles are separated by an artificial membrane which is not permeable to $\mathrm{O}_{2}$ or $\mathrm{H}_{2}$. After 01 son (ref. 12). 